\title{
Preface to the English Edition
}

In the aftermath of the 2004 tsunami in Southeast Asia, Clifford Geertz commented with melancholy, in the New York Review of Books on March 24 of the following year, that "fatality on such a scale, the destruction not only of individual lives but of whole populations of them, threatens the conviction that perhaps most reconciles many of us, insofar as anything this-worldly does, to our own mortality: that, though we ourselves may perish, the community into which we were born, and the sort of lives it supports, will somehow live on." One could extend this profound insight by suggesting that the significance of such a fatality is not only about our mourning of a possibly lost world, of which all traces may even disappear; it is also about our sense of belonging to a wider moral community, whose existence is manifested through compassion toward the victims. For the attentive observer of the tsunami, the impressive magnitude of the toll, with its tens of thousands of casualties, was as meaningful as the unparalleled deployment of solidarity, with its billions of dollars of aid. We lamented their dead but celebrated our generosity. The power of this event resides in the rare combination of the tragedy of ruination and the pathos of assistance. Such disasters now form part of our experience of this-worldliness, just as do aid organizations, relief operations, and humanitarian interventions. We have become used to the global spectacle of suffering and the global display of succor. The moral landscape thus outlined can be called humanitarianism. Although it is generally taken for granted as a mere expansion of a supposed natural humaneness that would be innately associated with our being human, humanitarianism is a relatively recent invention, which raises complex ethical and political issues. This book is about this invention and its complications. 
Humanitarianism has become familiar through catastrophic events, the images of which have been disseminated by the media, but it has also to do with more ordinary situations closer to us. Indeed, it is a mode of governing that concerns the victims of poverty, homelessness, unemployment, and exile, as well as of disasters, famines, epidemics, and wars—in short, every situation characterized by precariousness. It involves nongovernmental organizations, international agencies, states, and individuals. It mobilizes sympathy and technology, physicians and logisticians. Its sites of action are clinics for the poor and refugee camps, a social administration where undocumented immigrants are received and a military garrison where earthquake victims are treated. The case studies I have brought together here represent an attempt to account for this government of the precarious in its diversity during the past two decades. The first part involves policies and actors in France, the second explores scenes from South Africa, Venezuela, Palestine, and Iraq, with a transition following the transnational circulation between the Third World and Europe. This assemblage poses two questions.

First, how specific is the French case? It is true that important humanitarian organizations were founded in France, that French governments often included secretaries for humanitarian affairs, and that France played a prominent role in the promotion of humanitarian policies within international institutions, including the United Nations. It is obvious too that France has a long history of private charitable works emanating from Christian orders as well as public solidarity policies translated into social security, state medical aid, and most recently universal medical coverage, all elements that have resulted in a relatively distinct set of shared political and moral values. There is thus definitely a singularity of the French relationship with humanitarianism. However, the phenomena I describe and analyze in the case studies extend beyond the national boundaries in which they are inscribed. The tensions between compassion and repression, the problems posed by the mobilization of empathy rather than the recognition of rights, the prejudices toward the dominated and their consequences regarding the way to treat them have a high degree of generality that make them relevant in various contexts. Configurations may be different, but processes are similar.

Second, how coherent is the arrangement of such diverse geographical cases? The initial series of cases was situated in France and concerns its management of the disadvantaged, while South Africa, Venezuela, and Palestine yield three paradigmatic humanitarian scenes-that is, respectively, epidemics, disasters, and conflicts-with the final study illustrating the 
ambiguous links between aid workers and armed forces in military interventions such as in Iraq. The central hypothesis that holds these various worlds together is that they are inscribed in the same humanitarian governing process, whether it deals with the poor and the undocumented in the North or Aids orphans and flood victims in the South, with comparable moral categorizations and judgments, analogous developments of moral communities and exclusions, and equivalent consequences in terms of negation of voices and histories. Examining these distant scenes through the same lens is indispensable to comprehending the larger issues at stake in our moral economies.

The argument of this book is therefore that humanitarianism has become a potent force of our world. Its dissemination is so widespread that the tears shed by the Chinese prime minister over the devastation of the province of Sichuan increased his popularity, just as the apparent indifference of the president of the United States to the tragic consequences of Hurricane Katrina demonstrated the emptiness of his campaign slogan of compassionate conservatism. Its invocation is so powerful that it can serve as grounds for military action, allegedly to protect endangered populations, sometimes foregoing alternative options as in Kosovo or forging evidence as in Kuwait, or can even be used, as in the case of Augusto Pinochet in Britain and Maurice Papon in France, to exempt individuals accused or convicted of crimes against humanity from facing justice and punishment. It is this global and yet uneven force that I attempt to analyze here.

The year 2010 began with the dreadful earthquake in Haiti, which precipitated a remarkable mobilization worldwide, particularly from France and the United States. We witnessed in fact a competition between the two countries, whose governments and populations rivaled each other in solicitude toward the victims, bounteously sending troops, physicians, goods, and money, while raising the suspicion of the pursuit of goals other than pure benevolence toward a nation that was successively oppressed by the former and exploited by the latter. This emulation was certainly triggered by goodwill, and one should not minimize the altruistic engagement and charitable efforts of individuals, organizations, churches, and even governments involved in the treatment of the injured and later in the reconstruction efforts. Yet one cannot avoid thinking how rewarding was this generosity. For a fleeting moment we had the illusion that we shared a common human condition. We could forget that only $6 \%$ of Haitian asylum seekers are granted the status of refugee in France, representing one of the lowest national rates, far behind those coming from apparently peaceful countries, or that thirty thousand Haitians were on the deportation lists of the U.S. 
Immigration and Customs Enforcement Agency. The cataclysm seemed to erase the memories of the French and subsequent American exploitation of the island. Our response to it signified the promise of reparation and the hope for reconciliation.

In contemporary societies, where inequalities have reached an unprecedented level, humanitarianism elicits the fantasy of a global moral community that may still be viable and the expectation that solidarity may have redeeming powers. This secular imaginary of communion and redemption implies a sudden awareness of the fundamentally unequal human condition and an ethical necessity to not remain passive about it in the name of solidarity-however ephemeral this awareness is, and whatever limited impact this necessity has. Humanitarianism has this remarkable capacity: it fugaciously and illusorily bridges the contradictions of our world, and makes the intolerableness of its injustices somewhat bearable. Hence, its consensual force.

This morally driven, politically ambiguous, and deeply paradoxical strength of the weak I propose to call humanitarian reason.

Princeton, December 8, 2010 